\title{
Edible Coatings in Fruits -A Review
}

\author{
K. Susmitha Reddy and Jatinder Singh* \\ School of Agriculture, Dept. of Horticulture, Lovely Professional University, \\ Phagwara, Punjab, India \\ *Corresponding author
}

K e y w o r d s
$\begin{aligned} & \text { Edible and } \\ & \text { semipermeable } \\ & \text { coatings, Food } \\ & \text { additives, Fruits, } \\ & \text { Shelf life }\end{aligned}$
Article Info
$\begin{aligned} & \text { Accepted: } \\ & 20 \text { October } 2020 \\ & \text { Available Online: } \\ & \text { 10 November } 2020\end{aligned}$

\section{A B S T R A C T}

Low shelf life is the major problem in fruits, which affects consumer preference and marketability. Transpiration process starts after harvesting of fruits from plant, which lead to loss of quality along with shriveling, and ultimately shortens the life of the fruit. Many research experiments are conducted related to storage and packaging for increasing the shelf life of fruits like modified and controlled atmospheric storage/packaging, coatings. Coatings provide an extra protection layer to the fruit and help in increasing shelf life. Edible coatings made with edible materials that act as a barrier to water vapor and gases. These coatings act as the best alternatives to natural coverings by improving external appearance and changing internal atmosphere, which ultimately influences the shelf life. Application of semipermeable coatings reduces moisture loss, respiration, and transpiration, which increases the storage life of the commodity. The addition of food additives like pigments, antioxidants, antimicrobials, and antifungal substance helps in reducing postharvest decay in fruits.

\section{Introduction}

Consumers are demanding, globally, for high quality food which is without chemical substances and having stretched shelf life (Lin and Zhao, 2007). On the contrary, fruits are highly perishable in nature, as they contain enough quantity of water. After their harvesting, transpiration process starts quickly, which lead to loss of quality along with shriveling and ultimately shortens the life of the fruit. Problems like flaccidity, shriveling, wilting and decay etc. occur during postharvest management of fruits that ultimately influence marketability of the same including consumer preference. Today different kinds of preservation technologies are available for the post-harvest 
management. A potential awareness among the consumers concerning health aspect has raised consumers' attention towards natural plant extracts, to be used as coating material (Bhat et al., 2011). Such kind of post-harvest technology, aims at encompassing storage/shelf life of fruits by using natural plant-products. These edible coatings have drawn substantial attention in recent times as they have lot of advantages over synthetic/chemicals ones. They offer good alternative as they improve external appearance, and adjust the internal atmosphere of fruits. Moreover, such kind of postharvest losses can be lessened by stretching shelf life by checking microbial infection, transpiration and respiration rate and preventing disorganization of cell membranes (Bisen and Pandey, 2008). Such coatings act as decent oxygen and lipid blockade at lower RH because the polymers can efficiently make hydrogen bonds. These coatings also have antimicrobial or antioxidants property that reduces the decay without influencing quality. Today various kinds of chemical fungicides are the principal means for regulating postharvest fungal decay of fruits. An attempt in lessening, postharvest loss of tomato fruit caused by phytophthora infestans is good example, where certain fungicidal coatings are discussed (Ghatak et al., 2015). Adewoyin (2017) observed longer shelf life of pepper fruits, which are packaged in the aluminum foil than others and the main aim of this article was to assemble and update the statistics accessible on plant based natural coatings for quality, safety, and functionality of fruits. Such edible coatings are biodegradable and offer a good alternative to the other packaging. Therefore, the precise knowledge of such developments is of vital significance in developing effective tactics to improve quality including shelf-life of perishable natured fruits. Edible coating is well-defined as a thin layer edible material applied to the fruit surface in addition to or as a replacement for natural protecting waxy layers and to offer a barrier to moisture, oxygen, and solute movement for the food. Edible coating is an ecofriendly technology applied on many products to control gas exchange or oxidation processes and moisture transfer. They offer an extra protecting covering to the commodity and furthermore give the similar results as in case of modified atmosphere storage by adjusting internal gas structure. Nawab et al., (2017) told that the coatings form a semi-permeable barrier to gas exchange and water vapor, results in alteration of respiration rate, reduction of weight loss, and delay of senescence. In addition to acting as gas and moisture barriers, the coatings control microbial growth, preserve the texture, color and moisture of the product, and thus effectively prolong the shelf life of the product. Incorporation of other active ingredients in edible films and coatings enhances the safety and nutrition value of the fruits and vegetables. Food grade extracts including flavouring agents, pigments, antioxidants and antimicrobials can be added to modify their structure and advance characters of coatings, which when applied on produce increases its quality.

\section{Methods for coating}

The coating is applied through various methods contains dipping, brushing or spraying, on the food surface in order to make a modified atmosphere. Edible coatings can be applied by the simple methods like dipping products in coating materials and let them dry and solidify. Atieno (2019) observed no significant difference between spraying and dipping methods on cassava root to maintain post-harvest quality with xanthan/guar gum. Thus, edible films and coatings do not change traditional packaging materials but provide an extra support to fruits for their preservation. 


\section{Effect of edible coatings on fruit crops}

\section{Effect on external appearance and glossiness}

External appearance is an important aspect of the horticulture commodity. Rough physical management of fruits at postharvest phase is one of the major reasons to destroy of natural wax layer and bruising injury during the packing and transport operations. The edible coating offers a physical barrier between the fruit surface and the external surrounding of produces, which eventually lead to preservation of postharvest quality. Javanmard, (2011) observed whey protein concentrate show high rate of glossiness, taste, color and minimum weight loss over gellan gum coatings.

\section{Effect on fruit firmness and softening}

Edible coating keeps the firmness by evading excessive transpiration and respiration those involved directly in lessening storage reserves. Edible coating directly shows effect on fruit firmness by decreases the activity of cell wall degrading enzymes and delaying ripening. It is known that calcium directly affects fruit firmness thus the incorporation of calcium in the edible coating was also showed high effective in increasing fruit firmness. Zhang et al., (2018) discovered weight loos of the apricot was significantly reduced by the soybean isolated protein combined with chitosan along with preventing decrease in firmness and benefiting external characters.

\section{Effect on weight loss of fruits}

The weight of horticulture product governs the returns of farmers. Transpiration is the main reason of loss of weight of particular product, which is determined by the change of water vapour pressure between the fruit and the atmosphere. Edible coatings perform as an added barrier between the fruit surface and atmosphere, by which transpiration occurs. Hazrati (2017) reported that coating of peaches with aloe-vera L gel showed significantly positive effects on weight loss, change in color and TSS over control.

\section{Impact on physiology of fruit}

Physical state of the fruit is altered by the factor like fruit respiration, ethylene production rate etc. which plays important role in altering fruit physiology. An edible coating shows direct as well as indirect effect on the physiology of harvested commodities. Tesfay (2017) demonstrated that avocado fruits (varieties Hass and Geem) showed lower respiration, ethylene production and higher firmness when coated with $1 \%$ carboxyl methylcellulose, moringa leaf and seed extract throughout the storage period.

\section{Ethylene production and respiration}

The edible coating stops the entry of oxygen inside the fruit which controls the ethylene production and drops respiration rate. Thus, the fruits remain fresh, firm, and nutritious for a longer period and their shelf life almost doubles. The natural coating on fruits, the type of added coating and amount of coating will extent the formation of the internal modified atmosphere $\left(\mathrm{O}_{2}\right.$ and $\left.\mathrm{CO}_{2}\right)$. Nasrin (2020) observed the lemon coated with coconut oil-beeswax (90:10 and 80:20) or only coconut oil coating and kept in MAP showed extending in shelf life and quality maintenance like colour retaining, reducing ethylene production, respiration rate, weight loss and shriveling and preserved moisture content and firmness.

\section{Biochemical parameters}

Other than physical and physiological changes, edible coatings have a direct and 
indirect part in altering the biochemical constituents, which are responsible for taste and shelf life of the fruits. These include viz. titratable acidity, total soluble solids and ascorbic acid. Hosseini (2018) observed the reducing weight loss, positive effect in maintaining vitamin $\mathrm{C}$, and good sensory acceptability of kumquats which are treated with chitosan coatings incorporated with savory and/or tarragon essential oils.

\section{Total phenolic and antioxidants}

Presence of phenolic and antioxidants influences the shelf life of the fruits and vegetables. Presence of these compounds increases the resistance to various postharvest quality maintain factors. Shelf life of the fruits and vegetables increased by antioxidants from internal present and also by external application. Edible coatings have effect and ability to alter/ increase the antioxidant and also total phenolic content in harvested horticultural commodities shows same effect as antioxidants. Li (2017) observed positive effects on fruit quality and highest relative activities of antioxidants enzymes in chitosan based strawberry fruits over alginate and pullulan coatings,

\section{Lipid peroxidation and enzymatic activities}

Edible coating shows influence on the cell wall related enzymes activity. The effect is reported in case of enzymes such as polyphenol oxidase, phenylalanine ammonia lyase, and malondialdehyde which have an important role in cell wall degradation and peel browning. Edible coatings also regulate the process of lipid peroxidation which is responsible for cell wall breakdown and free radicals' generation which eventually affects postharvest quality. Panahirad (2020) observed the plum fruits coated with $1 \%$ carboxymethylcellulose, $1.5 \%$ pectin-based coatings and $0.5 \%$ pectin $+1.5 \%$ carboxymethylcellulose combination preserved firmness and improved anthocyanin, total phenols, antioxidant capacity, flavonoid content and peroxidase content and delayed vitamin C loss, titratable acidity and decreased enzymatic activity such as polyphenol oxidase and polygalacturonase.

\section{Classification of commercial forms of edible coatings}

Gutiérrez (2018) stated that edible coatings are produced from polymers which are categorized as hydrocolloids, lipids and their compounds. According to Valencia and do Amaral Sobral (2018) polysaccharides and protein are the vastly used structural resources for edible coatings. They are more tasteless, transparent and neutral, than those produced from lipids. Garrido et al., (2018) stated that edible coatings and films formed from polysaccharides or proteins usually provides good mechanical strength and good oxygen barriers. However, these materials are hydrophilic in nature, thus they are considered as poor water vapor barriers.

On the other hand, lipids (fats and oils) are excellent hydrophobic materials and less permeable to water vapor. Galus and Kadzińska (2015) stated that the hydrophilic character of polysaccharide and protein-based materials can be improved efficiently by combination of lipids.

In recent studies of Merino et al., (2019) on edible film preparing materials, the combination of different proteins, lipids and/or polysaccharides can be observed. The purpose of these researches is to use different properties of each factor in order to get new coating materials with better functional properties which depend on their compatibility and miscibility.

According to Álvarez et al., (2017) among polysaccharides, lipids and proteins, additional composites are generally required 
in order to provide flexible and continuous structure of coatings and films. Plasticizers are used to bound negative properties such as brittleness cracking or fragility. Medina et al., (2016) stated that oligosaccharides, lipids, and polyphenols are different kinds of plasticizers used in edible coatings and are hydrocolloids. In addition, water plays an important role as a plasticizer and shows difference in physical properties of films.

Salgado et al., (2015) stated that the use of bioactive ingredients and biopolymers obtained from agricultural waste or byproducts encourages the development of these global friendly resources which can substitute or at least bound the use of conventional plastics.

Galus et al., (2020) review about the new materials in the preparation of the edible coatings and films like plant residues, gums and flours and their preparation and applications.

\section{Polysaccharides derived edible coatings}

Polysaccharide based coatings are highly used edible coatings in fruits and vegetables. These polysaccharides are prepared from various plant species. These coatings have ability to prevent gases exchange, ability to reduce the water loss, and controls ripening and senescence. Crystalline property of some polysaccharides is reason for cross linkage which helps in a better coating. The most commonly used polysaccharide-based coatings include cellulose, chitosan and gums prepared from various plant species. Panahirad et al., (2020) observed improvement of postharvest quality of plum by application of different polysaccharide based coatings, stated application of $1 \%$ carboxymethylcellulose, $1.5 \%$ pectin based edible coatings and $0.5 \%$ pectin+ $1.5 \%$ carboxymethylcellulose combinations improved anthocyanin, total phenols and flavonoid contents, antioxidant capacity and POD activity, delayed titratable acidity and vitamin C loss, and decreased enzymatic activities such, polyphenol oxidase and polygalacturonase.

\section{Cellulose based edible films}

Cellulose is the polysaccharide produced from plants. Like methylcellulose, hydroxypropyl cellulose (HPC), carboxymethyl cellulose (CMC), and hydroxypropyl methylcellulose (HPMC) have good film-forming properties. These are usually transparent, tasteless, odorless, flexible, and of moderate strength, water-soluble, resistant to fats and oil, and resistant to oxygen and moisture transmission. The properties of cellulose edible coating affected due to the molecular weight, higher the molecular weight or concentration better are the quality of coating.

\section{Starch based edible films}

Starch is a complex form of carbohydrate which is made up of long chain of sugar or glucose molecules. Starch is the storage polysaccharide found in legumes, cereals, and tubers vegetables, like potato, cassava, corn, rice, banana etc. It is a good barrier to oxygen transmission but poor to water vapour. It used for coating vegetables and fruits which shows high respiration rates. Sapper and Chiralt (2018) explained about different starch-based coatings used to preserve the fruits and vegetables along with the factors affecting the coating efficiency.

\section{Gum based edible films}

The gums are formulated from polysaccharide. They include exudate gums (gum Arabic), extractive gums (guar and locust bean) and microbial fermentation gums (gellan and Xanthan). 


\section{Pectin based edible films}

Pectin is common compound found in plant mainly in fruits and vegetables like Guava, Apple etc. Pectin is a polysaccharide made up of galactouronic acids. Pectin is used as coating because of its thickening property and resistant lipids migration and moisture loss. According to Yoosef (2014) Strawberries coated with pectin shown less changes in weight loss, firmness, and also less microbial infection. Menezes and Athmaselvi (2016) reported that pectin-based coatings delay the shelf life of sapotaxfruit by delaying both physical and chemical changes during room temperature.

\section{Chitosan based edible films}

Chitosan is derived from chitin; it is an edible polymer, which is made by treating the chitin shells of shrimp and other crustaceans with an alkaline substance, like sodium hydroxide. It is a natural product which is non-toxic and eco-friendly. Chitosan has an antibacterial and antifungal property which helps in food protection. These films are flexible, tough, high durable and very difficult to tear. Chitosan is easily blend with starch and other essential oils; in different combinations it is helpful in increasing shelf life of fruits and vegetables. Chitosan coating regulate gas exchange, reduce transpiration losses thus delays the ripening, modify the fruit internal atmosphere. Rayees et al., (2013) observed that chitosan not only retains firmness but also increases the postharvest quality during cold storage. Xing et al., (2016) suggested that chitosan-based coating with antimicrobial properties have wide range of capacity in preservation of fruits and vegetables

\section{Proteins derived edible coatings}

Protein based edible coatings are generally combined with plasticizers or other compounds to increase the physical properties of that films. Proteins are used as coating material to avoid the moisture loss and to improve the shelf life of the product. Shendurse (2018), explained about the preparation, properties and food application of milk based edible coatings. Certain examples include casein, collagen, gelatin, whey protein, egg white protein, keratin, soy protein, wheat gluten, peanut protein, and corn-zein and cotton seed protein.

\section{Casein derived edible coating}

Casein is a major dairy protein, commonly used in the preparation of emulsion. Casein coatings resist oxygen transmission and humidity. These coatings dissolve quickly in water and less stretchy. Chen et al., (2019) reported caseins are desirable biomaterials for the preparation of edible coatings because of the solubility in water, emulsification capability and their high dietary benefits.

\section{Soy protein derived edible coating}

These are isolated chitosan that helps to maintain the firmness and reduces the weight loss of the products by providing an excellent barrier against oxygen and poor control of moisture and water vapor. The stability of the soy protein depends on the $\mathrm{pH}$ and ionic strength. Kang et al., (2013) reported that soybean protein is suitable for edible coating because of their low permeability to $\mathrm{CO}_{2}, \mathrm{O}_{2}$ and of its reasonable cost.

\section{Bee wax and paraffin wax}

It is a natural wax produced by honey bees of the genus apis are widely used after purification. This coating is highly used in mixing with either chitosan or cellulose based coatings. Shahid and Abbasi (2011) evaluated the influence of bee wax coating to maintain physical and biochemical parameters of sweet orange. 


\section{Algae derived edible coatings}

Alginate is a polysaccharide which is naturally derived from brown algae. These algae based edible coatings helps in increasing fruit quality and extending shelf life of the products. Alginate is excellent barrier to moisture, water vapour and oxygen by which it controls respiration. Huertas et al., (2012) observed delayed physical and chemical parameters of sweet cherry fruit by using different concentrations of sodium alginate $(1 \%, 3 \%$ and $5 \% \mathrm{w} / \mathrm{v})$.

\section{Plasticizers and antimicrobial compounds}

Most of the protein and polysaccharide-based coatings are brittle in nature, to solve this problem plasticizers are used to improve flexibility. Glycdrol, sucrose, polyethylene glycol, and acetylated monoglyceroide, are used as a plasticizer material for coating of vegetables and fruits.

Essential oils such as lemongrass, cinnamon, clove, oregano, thyme, rosemary, tea tree and bergamot and enzymes such as lysozyme, peroxidase and lacto peroxidase have been used to prepare emulsion coating which gives protection against postharvest pathogenic spoilage. Natural antioxidants such as tocopherols, tocotrienols, ascorbic acid, carotenoids, citric acid are also used. Saleem (2019) observed the persimmon fruits coated with gum arabic coating prevent spoilage along with extending shelf life.

\section{Herbal coatings}

Herbal coatings are generally extracted from aloe gel, neem, tulsi, lemon grass, turmeric and rosemary. Among these aloe gel coating shows best result on mangoes, nectarines, strawberries, apples, cherries, papayas, plums, peaches, tomatoes and table grapes. The gel is colorless, tasteless, odorless, environmentally friendly and transparent in nature. Other than these extracts from ginger, garlic, Canthiumhorridu, Macarangahemsleyana, Vaticamangachapoi, Hainaniatrichosperma have antimicrobial properties. These consists antioxidants, essential minerals and vitamins. Saha (2017) reviewed about plant derived natural gums and their derivatives as edible coatings which are nontoxic, biodegradable, easily available and economical. Ribeiro et al., (2020) summarized the information related to the incorporation of natural extracts in the coatings and films, preparations challenges and opportunities (Table 1 and 2).

Table.1 Ingredients used in the preparation of edible films and coatings

\begin{tabular}{|l|l|l|l|}
\hline Source & Polysaccharides & Proteins & Lipids \\
\hline Vegetables & $\begin{array}{l}\text { Cellulose and cellulose } \\
\text { derivatives, pectin, starch, } \\
\text { tara gum }\end{array}$ & $\begin{array}{l}\text { Soy proteins, } \\
\text { wheat gluten, corn } \\
\text { zein }\end{array}$ & $\begin{array}{l}\text { Vegetable oils, nut oils, } \\
\text { seed oils, candeilla, rice } \\
\text { bran wax, carnauba wax, }\end{array}$ \\
\hline Animals & Chitosan & $\begin{array}{l}\text { Gelatin, collagen, } \\
\text { milk proteins, egg } \\
\text { proteins, } \\
\text { myofibrillar } \\
\text { proteins }\end{array}$ & Beeswax, fish oil, shellac \\
\hline
\end{tabular}


Table.2 Utilization of different coatings for shelf life extension in various fresh fruits Tropical and Sub-tropical Fruits

\begin{tabular}{|c|c|c|c|}
\hline Fruit & Coating & Result & Reference \\
\hline \multirow[t]{3}{*}{ Guava } & Guar gum & $\begin{array}{l}\text { Guar gum in water } \\
\text { resulted in } \\
\text { disinfestation. This } \\
\text { treatment is effective in } \\
\text { extending of shelf life } \\
\text { of the fruit and shows } \\
\text { disinfestation activity } \\
\text { against fruit flies. }\end{array}$ & $\begin{array}{l}\text { Esameldin et al., } \\
\text { (2018) }\end{array}$ \\
\hline & $\begin{array}{lr}\text { Chitosan cassava starch } \\
\text { supplemented with } \\
\text { Lippiagracilis } & \text { and } \\
\text { Schauer genotype } & \end{array}$ & $\begin{array}{lr}\text { Formulations } \\
\text { containing } \\
\text { chitosan and } & 2.0 \%, 2.0 \\
\% \quad \text { or } & 3.0 \% \\
\text { Lippiagracilis } & \text { Schauer } \\
\text { genotype, } 2.0 \% & \text { cassava } \\
\text { starch, were utmost } \\
\text { influenceable } \\
\text { decreasing the growth } \\
\text { of gram - negative and } \\
\text { gram- positive bacteria } \\
\text { in vitro and suspending } \\
\text { the ripening. }\end{array}$ & $\begin{array}{l}\text { Aquino et al., } \\
\text { (2015) }\end{array}$ \\
\hline & $\begin{array}{l}\text { Chitosan and alginate } \\
\text { along with peel extract } \\
\text { of pomegranate }\end{array}$ & $\begin{array}{l}\text { Alginate along with } \\
\text { Chitosan and coating } \\
\text { combination with } \\
\text { pomegranate } \\
\text { extract (PPE; } 1 \% \text { peel } / \mathrm{v} \text { ) } \\
\text { increased the quality of } \\
\text { guavas during storage at } \\
\text { low temperature. }\end{array}$ & $\begin{array}{l}\text { Sneha et al., } \\
\quad(2018)\end{array}$ \\
\hline Banana & $\begin{array}{l}\text { Cellulose nanomaterials } \\
\text { emulsion as coatings }\end{array}$ & $\begin{array}{l}\text { Cellulose nanofiber- } \\
\text { based emulsion varnish } \\
\text { had low angle of } \\
\text { interaction, maximum } \\
\text { spread coefficient onto } \\
\text { fruit surfaces and also } \\
\text { lowers surface tension } \\
\text { than the critical ST of } \\
\text { banana peels, and } \\
\text { displays } \\
\text { wettability good } \\
\text { surfaces. } \\
\text { deferment ento }\end{array}$ & $\begin{array}{l}\text { Deng } \\
(2017)\end{array}$ \\
\hline
\end{tabular}




\begin{tabular}{|c|c|c|c|}
\hline & & $\begin{array}{lr}\text { biosynthesis } & \text { and } \\
\text { thereby } & \text { increasing } \\
\text { storage. } & \end{array}$ & \\
\hline \multirow[t]{3}{*}{$\begin{array}{l}\text { Kinnow } \\
\text { mandarin }\end{array}$} & $\begin{array}{l}\text { Chitosan based coatings } \\
\text { with Cinnamaldehyde }\end{array}$ & $\begin{array}{l}\text { CI-CH effectively } \\
\text { decreased the fruit } \\
\text { decay rate, improved } \\
\text { the quality of fruits }\end{array}$ & $\begin{array}{l}\text { Gao et al., } \\
\text { (2018) }\end{array}$ \\
\hline & $\begin{array}{l}\text { Hydroxyl-propyl- } \\
\text { methylcellulose coating } \\
\text { combination with } \mathrm{CaCl}_{2} \\
\text { and } \mathrm{MgSo}_{4}\end{array}$ & $\begin{array}{l}\text { Treating kinnow fruits } \\
\text { with combination of } \\
\mathrm{CaCl}_{2}+\mathrm{MgSO}_{4}+ \\
\mathrm{HPMC} \text { helped to } \\
\text { sustain firmness, } \\
\text { minimize loss in weight } \\
\text { and ethylene production } \\
\text { with improved values of } \\
\text { acidity and vitamin c } \\
\text { contents. Minimum } \\
\text { TSS is also observed } \\
\text { which advances shelf } \\
\text { life of kinnow. }\end{array}$ & $\begin{array}{l}\text { Randhawa et al., } \\
\text { (2018) }\end{array}$ \\
\hline & $\begin{array}{l}\text { Polysaccharides from } \\
\text { opuntia coating in } \\
\text { kinnow }\end{array}$ & $\begin{array}{l}2 \% \text { cactus } \\
\text { polysaccharides retain } \\
\text { maximum moisture, } \\
\text { maximum value for pH } \\
\text { of coated citrus while } \\
3.19 \% \text { cactus } \\
\text { polysaccharides coating } \\
\text { increases the shelf life } \\
\text { and quality of the fruit. }\end{array}$ & $\begin{array}{l}\text { Riaz et al., } \\
\quad(2018)\end{array}$ \\
\hline $\begin{array}{l}\text { Persian } \\
\text { lime }\end{array}$ & $\begin{array}{l}\text { Soy protein-based } \\
\text { coatings including some } \\
\text { antimicrobial } \\
\text { compounds }\end{array}$ & $\begin{array}{l}\text { Regulates infestation of } \\
\text { blue mould, lessens } \\
\text { water loss and thus } \\
\text { maintains colour. }\end{array}$ & $\begin{array}{l}\text { González- } \\
\text { Estrada et al., } \\
\quad(2017)\end{array}$ \\
\hline Orange & $\begin{array}{l}\text { Sellac, gelatin and } \\
\text { Persian gum as alternate } \\
\text { coatings }\end{array}$ & $\begin{array}{l}\text { Coating of } 3.5,4 \text { and } \\
4.5 \% \text { Persian gum, } 5,6 \\
\text { and } 7 \% \text { gelatin, } 9,10 \\
\text { and } 11 \% \text { shellac gave } \\
\text { satisfactorily results. }\end{array}$ & $\begin{array}{l}\text { Khorram et al., } \\
\quad(2017)\end{array}$ \\
\hline Strawberry & $\begin{array}{l}\text { Lemon peel essential oil } \\
\text { with cassava starch and } \\
\text { sodium alginate }\end{array}$ & $\begin{array}{l}\text { They reduced the } \\
\text { degradation process. } \\
\text { Essential oil of lemon }\end{array}$ & $\begin{array}{c}\text { Rahmawati et } \\
\text { al., } \\
(2017)\end{array}$ \\
\hline
\end{tabular}




\begin{tabular}{|c|c|c|c|}
\hline & & $\begin{array}{l}\text { peel }(0.6 \%) \text { showed } \\
\text { important action as an } \\
\text { antimicrobial agent } \\
\text { against many bacteria } \\
\text { sp like bacillus sp. etc } \\
\text { but lemon peel essential } \\
\text { oil is helps in inhibition } \\
\text { of Botrytis sp and } \\
\text { Rhizopus stolonifera } \\
\text { like pathogens. }\end{array}$ & \\
\hline & $\begin{array}{l}\text { Banana starch chitosan, } \\
\text { Aloe Vera gel coating }\end{array}$ & $\begin{array}{l}\text { Aloe vera } 20 \% \text {, when } \\
\text { used as coating, greatly } \\
\text { improves } \\
\text { physicochemical } \\
\text { properties, such as } \\
\text { colour and firmness and } \\
\text { weight loss was also } \\
\text { reduced. }\end{array}$ & $\begin{array}{l}\text { Pinzon } \text { et al., } \\
\quad(2020)\end{array}$ \\
\hline & $\begin{array}{l}\text { Three polysaccharide- } \\
\text { based coatings } \\
\text { (alignate, chitosan and } \\
\text { pullulan) }\end{array}$ & $\begin{array}{l}\text { Such polysaccharide } \\
\text { coatings also continued } \\
\text { total phenolic contents } \\
\text { and higher ascorbic acid } \\
\text { and significantly } \\
\text { decreased fruit decay } \\
\text { and respiration in } \\
\text { storage along with } \\
\text { antioxidant enzyme } \\
\text { activity. }\end{array}$ & $\begin{array}{l}\text { Li } \text { et al., } \\
\text { (2017) }\end{array}$ \\
\hline Blueberry & $\begin{array}{l}\text { Sodium alignate, Pectin, } \\
\text { Sodium alignate plus } \\
\text { pectin }\end{array}$ & $\begin{array}{l}\text { Advances fruit } \\
\text { firmness, decreases } \\
\text { yeasts growth including } \\
\text { aerobic bacteria. }\end{array}$ & $\begin{array}{l}\text { Mannozzi et al., } \\
\text { (2017) }\end{array}$ \\
\hline \multirow[t]{2}{*}{ Papaya } & Aloe Vera gel & $\begin{array}{l}\text { In this case aloe vera } \\
(1.5 \%) \text { maintained color } \\
\& \text { improved physical } \\
\text { changes in storage. It } \\
\text { proved to be helpful } \\
\text { extending the shelf-life } \\
\text { of papaya up to } 15 \text { days. }\end{array}$ & $\begin{array}{l}\text { Sharmin et al., } \\
\text { (2016) }\end{array}$ \\
\hline & $\begin{array}{l}\text { Carboxymethylcellulose } \\
\text { coating with essential } \\
\text { oil }\end{array}$ & $\begin{array}{l}\text { Combination of } L \text {. } \\
\text { sidoides EO with CMC } \\
\text { was proved to be better } \\
\text { to extend the shelf life } \\
\text { of papayas and also } \\
\text { maintained the post- } \\
\text { harvest characteristics. }\end{array}$ & $\begin{array}{l}\text { Zillo et al., } \\
\text { (2018) }\end{array}$ \\
\hline
\end{tabular}




\begin{tabular}{|c|c|c|c|}
\hline & $\begin{array}{l}\text { Chitosan and propolis } \\
\text { extract }\end{array}$ & $\begin{array}{l}\text { Chitosan (1\%) in } \\
\text { combination with } \\
\text { propolisethanolic } \\
\text { extract }(5 \%) \text { influenced } \\
\text { the postharvest handling } \\
\text { of the fruit. }\end{array}$ & $\begin{array}{l}\text { Barrera et al., } \\
\quad(2015)\end{array}$ \\
\hline \multirow[t]{3}{*}{ Mango } & $\begin{array}{l}\text { Chitosan and Calcium } \\
\text { Chloride }\end{array}$ & $\begin{array}{l}\text { Calcium chloride along } \\
\text { with chitosan acted as } \\
\text { an effective preserving } \\
\text { agent and improved of } \\
\text { the shelf life of mango } \\
\text { in storage. }\end{array}$ & $\begin{array}{l}\text { Shweta et al., } \\
\text { (2014) }\end{array}$ \\
\hline & $\begin{array}{l}\text { Cassava starch and } \\
\text { chitosan coatings }\end{array}$ & $\begin{array}{l}\text { Cassava starch, } \\
\text { chitosan, and cassava } \\
\text { starch/chitosan }(2 \%) \\
\text { helped in extending the } \\
\text { shelf life of the fruit. }\end{array}$ & $\begin{array}{l}\text { Oliveira et al., } \\
\quad \text { (2018) }\end{array}$ \\
\hline & $\begin{array}{l}\text { Gum Arabic coating } \\
\text { with calcium chloride }\end{array}$ & $\begin{array}{l}\text { Guar gum }(10 \%) \text { and } \\
\text { also in combination } \\
\text { with calcium chloride } \\
(3 \%) \text { was effective in } \\
\text { preserving fruit quality } \\
\text { but with low } \\
\text { temperature during } \\
\text { storage. }\end{array}$ & $\begin{array}{l}\text { Khaliq et al., } \\
\text { (2015) }\end{array}$ \\
\hline \multirow[t]{2}{*}{ Ber } & $\begin{array}{l}\text { Guar gum blended with } \\
\text { aloe Vera }\end{array}$ & $\begin{array}{lr}\text { Such } & \text { coating- } \\
\text { maintained } & \text { fruit } \\
\text { firmness, } & \text { colour } \\
\text { including acidity } & \text { under } \\
\text { ambient storage. }\end{array}$ & $\begin{array}{l}\text { Arghya M et al., } \\
\text { (2018) }\end{array}$ \\
\hline & $\begin{array}{l}\text { Chitosan, Guar gum and } \\
\text { Gum tragacanth } \\
\text { coatings }\end{array}$ & $\begin{array}{l}\text { Extended of shelf life of } \\
\text { the fruit. }\end{array}$ & $\begin{array}{c}\text { Nilesh } \\
\text { Bhowmick } \text { et al., } \\
\text { (2015) }\end{array}$ \\
\hline \multirow[t]{2}{*}{ Grapes } & $\begin{array}{l}\text { Native and octenyl } \\
\text { succinic anhydride } \\
\text { modified wheat starch } \\
\text { coatings }\end{array}$ & $\begin{array}{l}\text { Decreased spoilage of } \\
\text { grapes, extends shelf } \\
\text { life and sustaining the } \\
\text { fruit quality. Starch } \\
\text { based coating have } \\
\text { capacity to maintain } \\
\text { total carotenoids } \\
\text { including total phenolic } \\
\text { content and as well as } \\
\text { the shelf life and quality } \\
\text { of the fruit. }\end{array}$ & $\begin{array}{l}\text { Punia et al., } \\
\text { (2019) }\end{array}$ \\
\hline & $\begin{array}{l}\text { Chitosan nanoparticles } \\
\text { coatings }\end{array}$ & $\begin{array}{l}\text { Chitosan nanoparticles } \\
\text { as edible coatings can }\end{array}$ & $\begin{array}{l}\text { Castelo et al., } \\
\text { (2018) }\end{array}$ \\
\hline
\end{tabular}




\begin{tabular}{|c|c|c|c|}
\hline & & $\begin{array}{l}\text { improve the post- } \\
\text { harvest quality of } \\
\text { grapes to a great extent. }\end{array}$ & \\
\hline & $\begin{array}{l}\text { Shrimp chitosan and } \\
\text { Mentha essential oil }\end{array}$ & $\begin{array}{l}\text { Chitosan } \\
\text { combination } \\
\text { MPEO or MVEO } \\
\text { deferred the mold } \\
\text { growth and declined the } \\
\text { frequency of infections } \\
\text { caused by all fungi } \\
\text { types like Aspergillus } \\
\text { niger, Penicillium } \\
\text { expansum etc. in } \\
\text { grapes. }\end{array}$ & $\begin{array}{l}\text { Guerra et al., } \\
\text { (2016) }\end{array}$ \\
\hline $\begin{array}{l}\text { Guava, } \\
\text { Mango and } \\
\text { Papaya }\end{array}$ & $\begin{array}{l}\text { Chitosan and lemon } \\
\text { grass essential oil }\end{array}$ & $\begin{array}{l}\text { Anthracnose control } \\
\text { during postharvest } \\
\text { handling. }\end{array}$ & $\begin{array}{l}\text { Lima et al., } \\
\qquad(2018)\end{array}$ \\
\hline $\begin{array}{l}\text { Different } \\
\text { fruits }\end{array}$ & $\begin{array}{l}\text { Chitosan Mono-Bilayer } \\
\text { coatings }\end{array}$ & $\begin{array}{l}\text { Multilayered chitosan- } \\
\text { based coatings advance } \\
\text { quality characters and } \\
\text { regulation the } \\
\text { postharvest oxidative } \\
\text { stress in many fruits. }\end{array}$ & $\begin{array}{l}\text { Modesti et al., } \\
\text { (2019) }\end{array}$ \\
\hline
\end{tabular}

\begin{tabular}{|c|c|c|c|}
\hline Crop & Coating & Result & Reference \\
\hline Apple & $\begin{array}{l}\text { Aloe Vera, Neem oil and } \\
\text { marigold flower extracts as } \\
\text { coatings }\end{array}$ & $\begin{array}{l}\text { These coatings maintain the } \\
\text { storage quality of the same. }\end{array}$ & $\begin{array}{l}\text { Shweta et } \\
\text { al., } \\
(2014)\end{array}$ \\
\hline \multirow[t]{2}{*}{ Peach } & $\begin{array}{l}\text { Rhubarb extract in sodium } \\
\text { alginate-based coating }\end{array}$ & $\begin{array}{l}\text { They advance postharvest } \\
\text { traits and extend the shelf life } \\
\text { of the fruit. }\end{array}$ & $\begin{array}{l}\text { Xiao-yu et } \\
\text { al., } \\
\text { (2019) }\end{array}$ \\
\hline & $\begin{array}{l}\text { Mango peel and extract of } \\
\text { seed kernel }\end{array}$ & $\begin{array}{l}\text { Coating of mango peel, } \\
\text { extract of mango kernel and } \\
\text { glycerol showed less } \mathrm{CO} 2 \\
\text { and ethylene production and } \\
\text { less } \mathrm{O} 2 \text { consumption. }\end{array}$ & $\begin{array}{l}\text { Cristian et } \\
\text { al., } \\
(2018)\end{array}$ \\
\hline Pear & $\begin{array}{l}\text { Optimization of edible } \\
\text { coating formulations of soy } \\
\text { protein isolation, } \\
\text { hydroxypropyl } \\
\text { methylcellulose and olive } \\
\text { oil }\end{array}$ & $\begin{array}{l}\text { Effective combination for } \\
\text { less weight loss, improved } \\
\text { pH, TSS and TA values. }\end{array}$ & $\begin{array}{l}\text { Nandane } \\
\text { et al., } \\
\text { (2016) }\end{array}$ \\
\hline (Bartlett) & $\begin{array}{l}\text { Sempfresh along with } \\
\text { controlled atmosphere and } \\
\text { 1-methylcyclopropene }\end{array}$ & $\begin{array}{l}\text { The combination of } \mathrm{CA}+1- \\
\mathrm{MCP}+\mathrm{SF} \text { sustained } \\
\text { maximum storage quality }\end{array}$ & $\begin{array}{l}\text { Zhi et al., } \\
\text { (2018) }\end{array}$ \\
\hline
\end{tabular}




\begin{tabular}{|l|l|l|c|}
\hline & & $\begin{array}{l}\text { with improved colour, } \\
\text { firmness, and reductions in } \\
\text { ethylene production and } \\
\text { respiration activity. }\end{array}$ & \\
\hline $\begin{array}{l}\text { Plum } \\
\text { (Santa }\end{array}$ & Lac-based, Semeperfresh & $\begin{array}{l}\text { Lac-based coating retained } \\
\text { nearly } 55 \% \text { higher firmness }\end{array}$ & Kumar et \\
Rosa) & and Niprofresh coatings & $\begin{array}{l}\text { al., } \\
\text { and } 21 \% \text { higher antioxidant }\end{array}$ & (2018) \\
\hline
\end{tabular}

\section{References}

Abhijeet Ghatak, Mohammad Ansar, Lajja Vati Ghatak and Rekha Balodi, 2015, Elucidation of Relationship between Phytophthora Leaf Blight and Fruit Rot in Tomato. J. of Postharvest Tech. 03 (02): 050-057

Adewoyin O. B., 2017. Effects of packaging materials and storage conditions on storability of pepper (Capsicum frutescens L.) fruits, J. of Postharvest Tech. 05(4): 6270

AktarNasrin, T. A., Rahman, M. A., Arfin, M. S., Islam, M. N., and Ullah, M. A. (2019). Effect of novel coconut oil and beeswax edible coating on postharvest quality of lemon at ambient storage. JAFR, 100019. doi: 10.1016/j.jafr.2019.100019

Aquino, D., A. B., A. F. Blank and L. C. L. de Aquino Santana. 2015. Impact of edible chitosan-cassava starch coatings enriched with Lippiagracilis Schauer genotype mixtures on the shelf life of guavas (Psidium guajava L.) during storage at room temperature. Food Chem. 171: 108116.

Arghya M., V. S. S. V. Prasanna, H. Shuvadeep and J. Praveena. 2018. Efficacy of edible coatings blended with aloe Vera in retaining post-harvest quality and improving storage attributes in Ber (Ziziphus mauritiana Lamk.). IJCS. 6(6): 1727-1733.

Atieno, L., Owino, W., Ateka, E. M., and Ambuko, J., Influence of Coating Application Methods on the Postharvest Quality of Cassava, IJFS, Volume 2019, 116. doi:10.1155/2019/2148914
Barrera, E., J. Gil, A. Restrepo, K. Mosquera and D. Durango. 2015. A coating of chitosan and propolis extract for the postharvest treatment of papaya (Carica papaya L. cv. Hawaiiana). Rev.Fac.Nal.Agr. 68(2): 76677678.

Bhat, R., A.K. Alias and G. Paliyath. 2011. "Essential Oils and Other Plant Extracts as Food Preservatives", Progress in Food Preservation. New Jersey, John Wiley and Sons: 539-580.

Bisen. A and S. K. Pandey. 2008. Effect of postharvest treatment on biochemical composition and organoleptic quality in Kagzi lime fruit during storage. Journal of Horti. Sci. 3 (1): 53-56.

Castelo, B. M. N. F., B. L. de Mendonçasoares, D. K. Marques, C. L. Ferreira, D. Canto, M. A. P. Flores, T. C. M. Stamford. 2018. Effects of fungal chitosan nanoparticles as ecofriendly edible coatings on the quality of postharvest table grapes. J. Postharvest Bio and Tech. 139: 56-66.

Cristian Torres-Leóna, A. A. Vicenteb, L. María, Flores-Lópezb, R. Romeo, L. Serna-Cockd, B. Olga, Alvarez-Péreza, N. A. Cristóbal. 2018. Edible films and coatings based on mango (var. Ataulfo) by-products to improve gas transfer rate of peach. LWT Food Sci. and Tech. 97: 624-631

Deng, Z., J. Jung, J. Simonsen and Y. Zhao. 2017. Cellulose nanomaterials emulsion coatings for controlling physiological activity, modifying surface morphology, and enhancing storability of postharvest bananas (Musa acuminate). Food Chem 232: 359-368.

Esameldin B. M., G. H. A. Kabbashi and N. A. Abdlerahman. 2018. Guava (Psidium guajava L.) fruit coating with gum arabic 
for quality and fruit fly control. J. Exp Sci. 9: 01-04.

Galus, S., and J. Kadzińska. 2015. Food applications of emulsion-based edible films and coatings. Trends in Food Sci. and Tech. 45(2): 273-283.

Gao, Y., C. Kan, M. Chen, C. Chen, Y. Chen, Y. $\mathrm{Fu}$ and J. Chen. 2018. Effects of ChitosanBased Coatings Enriched with Cinnamaldehyde on Mandarin Fruit cv. Ponkan during Room-Temperature Storage. Coatings. 8: 372.

Garrido, T., Uranga, J., P. Guerrero, and K. d. 1. Caba. 2018. The potential of vegetal and animal proteins to develop more sustainable food packaging. In Polymers for food appli: 25-59. Springer, Cham.

González-Estrada, R. R., P. Chalier, J. A. Ragazzo-Sánchez, D. Konuk and M. Calderón-Santoyo. 2017. Antimicrobial soy protein based coatings: Application to Persian lime (Citrus latifolia Tanaka) for protection and preservation. J. Postharvest Bio and Tech. 132: 138-144.

Guerra, I. C. D., P. D. L. de, Oliveira, M. M. F. Santos, A. S. S. C. Lúcio, J. F. Tavares, J. M. Barbosa-Filho and E. L. de Souza. 2016. The effects of composite coatings containing chitosan and Mentha (piperita $\mathrm{L}$. or $\mathrm{x}$ villosaHuds) essential oil on postharvest mold occurrence and quality of table grape cv. Isabella. J. IFSET. 34: 112121.

Gutiérrez, T. J. 2018. Polymers for Food Applications: News. Polymers for Food Applications. 1-4. doi:10.1007/978-3-31994625-2_1

Hazrati, S., BeyraghdarKashkooli, A., Habibzadeh, F., Tahmasebi-Sarvestani, Z., \& Sadeghi, A. R. (2017). Evaluation of Aloe vera Gel as an Alternative Edible Coating for Peach Fruits During Cold Storage Period. Gesunde Pflanzen, 69(3), 131-137. doi:10.1007/s10343-017-0397-5

Hongbo, C., J. Wang, Y. Cheng, C. Wang, H. Liu, H. Bian, Y. Pan, J. Sun and W.n Han. 2019. Application of Protein-Based Films and Coatings for Food Packaging: A Review, Polymers. 11: 2039.

Hosseini, S. F., Amraie, M., Salehi, M., Mohseni, M., \&Aloui, H. (2018). Effect of chitosan- based coatings enriched with savory and/or tarragon essential oils on postharvest maintenance of kumquat (Fortunella sp.) fruit. FSN. doi:10.1002/fsn3.835

Huertas, M. D., S. María and V. Daniel. 2012. Alginate Coatings Preserve Fruit Quality and Bioactive Compounds during Storage of Sweet Cherry Fruit, Food Bioprocess Technol. 5:2990-2997. DOI 10.1007/s11947-011-0599-2

Javanmard. M. 2011, Shelf-Life of Apples Coated with Whey Protein Concentrate Gellan Gum Edible Coatings, J. FBT, IAU, 1, 55 62, 2011

Jorge A. Aguirre-Joya, Miguel A. De LeonZapata, Olga B. Alvarez-Perez, Cristian Torres-León, Diana E. Nieto-Oropeza, Janeth M. Ventura-Sobrevilla, Miguel A. Aguilar, XochitlRuelas-Chacón, Romeo Rojasł, MaríaElen, Ramos-Aguiñaga, Cristóbal N. Aguilar, 2017 Basic and Applied Concepts of Edible Packaging for Foods, Food Packag and Preserv. doi.10.1016/B978-0-12-811516-9.00001-4

Kang, H.-J., S.-J. Kim, Y.-S. You, M. Lacroix and J. Han. 2013. Inhibitory effect of soy protein coating formulations on walnut (Juglans regia L.) kernels against lipid oxidation. LWT - Food Sci. and Tech. 51(1): 393-396.

Khaliq, G., M. T. M. Mohamed, A. Ali, P. Ding and H. M. Ghazali. 2015. Effect of gum arabic coating combined with calcium chloride on physico-chemical and qualitative properties of mango (Mangifera indica L.) fruit during low temperature storage. Scientia Hort. 190: 187-194.

Khorram, F., A. Ramezanian, and S. M. H. Hosseini. 2017. Shellac, gelatin and Persian gum as alternative coating for orange fruit. Scientia Hort. 225: 22-28.

Kumar. P., S. Sethi, R. R. Sharma, M. Srivastav, D. Singh and E. Varghese. 2018. Edible coatings influence the cold-storage life and quality of "Santa Rosa" plum (Prunus salicina Lindell). J. Food Sci. and Tech. 55(6): 2344-2350.

Li, L., Sun, J., Gao, H., Shen, Y., Li, C., Yi, P., He, X., Ling, D., Sheng, J., Li, J., Liu, G., Zheng, F., Xin, M., Li, Z., and Tang, Y. (2017). Effects of Polysaccharide-Based 
Edible Coatings on Quality and Antioxidant Enzyme System of Strawberry during Cold Storage. IJPS, 2017, 1-8. doi:10.1155/2017/9746174

Li, Li, J. Sun, H. Gao, Y. Shen, C. Li, P. Yi and Y. Tang. 2017. Effects of PolysaccharideBased Edible Coatings on Quality and Antioxidant Enzyme System of Strawberry during Cold Storage. IJPS. Pp. 1-8.

Lima Oliveira, P. D., K. Á. R. de Oliveira, W. A. dos, S. Vieira, M. P. S. Câmara and E. L. de Souza. 2018. Control of anthracnose caused by Colletotrichum species in guava, mango and papaya using synergistic combinations of chitosan and Cymbopogon citratus (D.C. ex Nees) Stapf. essential oil. Int J Food Microbiol. 266: 87-94.

Lin, D. and Y. Zhao. 2007. Innovations in the Development and Application of Edible Coatings for Fresh and Minimally Processed Fruits and Vegetables. Comprehensive Reviews in Food Science and Food Safety. 6(3): 60-75.

Mannozzi, C., J. P. Cecchini, U. Tylewicz, L. Siroli, F. Patrignani, R. Lanciotti, and S. Romani. 2017. Study on the efficacy of edible coatings on quality of blueberry fruits during shelf-life. LWT - Food Science and Tech. 85: 440-444

Marisa Ribeiro. A, Berta N. Estevinho, F. Rocha, Preparation and Incorporation of Functional Ingredients in Edible, doi:10.1007/s11947020-02528-4

Medina, J., C., T. J. Gutiérrez, S. Goyanes, C. Bernal and Famá, L. 2016. Biodegradability and plasticizing effect of yerba mate extract on cassava starch edible films. Carbohydrate Polymers. 151: 150-159.

Menezes, J. and K. A. Athmaselv. 2016. Study on Effect of Pectin Based Edible Coating on the Shelf Life of Sapota Fruits, Biosci., Biotech. Res. Asia, Vol. 13(2), 1195-1199 (2016)

Merino, D., T. J. Gutiérrez and V. A. Alvarez. 2018. Potential Agricultural Mulch Films Based on Native and Phosphorylated Corn Starch with and Without Surface Functionalization with Chitosan. J. of Polymers and the Envi, doi:10.1007/s10924-018-1325-1

Modesti, M., L. Zampella and M. Petriccione.
2019. Chitosan Mono- and Bilayer Edible Coatings for Preserving Postharvest Quality of Fresh Fruit. Polymers for Agri-Food Appli. 465-486. Springer, doi: 10.1007/978-3-030-19416-1_23

Nandane, A. S., R. K. Dave and T. V. R. Rao. 2016. Optimization of edible coating formulations for improving postharvest quality and shelf life of pear fruit using response surface methodology. J. Food Sci. and Tech. 54(1): 1-8.

Nawab, A., Alam, F., \& Hasnain, A. (2017). Mango kernel starch as a novel edible coating for enhancing shelf- life of tomato (Solanum lycopersicum) fruit. I J bio mac, 103, 581-586. doi: 10.1016/j.ijbiomac.2017.05.057

NileshBhowmick, A. Ghosh, P. Du and K. Dey. 2015. Efficacy of edible coatings on the shelf life of ber (Zizyphus mauritiana Lamk.) fruits at ambient condition. IJAEB. 8(3): 601-608.

Oliveira T. A., C. A. Paiva, A. C. Silva, L. V. Nascimento, R. H. L. Leite and E. M. M. Aroucha. 2018. Postharvest Quality of Tommy Atkins Mangoes Coated with Cassava Starch and Chitosan-Based Coatings. JAS, Vol. 10, No. 11; 2018, ISSN 1916-9752 E-ISSN 1916-9760

Pandya, A.J., Milk protein based edible films and coatings- preparation, properties and food applications, J Nutr Health Food Eng. 2018;8(2):219-226. DOI: 10.15406/jnhfe.2018.08.00273

Pinzon, M.I., Sanchez, L.T., Garcia, O.R., Gutierrez, R., Luna, J.C. and Villa, C.C., 2020. Increasing shelf life of strawberries (Fragaria ssp) by using a banana starch- chitosan- Aloe vera gel composite edible coating. IJFS. 55(1):92-98.

Punia, S., K. S. Sandhu, S. B. Dhall, and M. Kaur. 2019. Dynamic, shear and pasting behaviour of native and octenyl succinic anhydride (OSA) modified wheat starch and their utilization in preparation of edible films. Int. Jour. Of Biologic Macromole. 133: 110-116.

Rahmawati, D., Chandra, M., Santoso, S., \&Puteri, M. G. 2017. Application of lemon peel essential oil with edible coating agent to prolong shelf life of tofu and strawberry. 
ISAC. 1803(1) p. 020037.

Randhawa, M. A., M. Arfan, I. Pasha, M. Nadeem and N. Ahmad. 2018. Synergistic Effect of Salts and Cellulose Based Coating on Shelf Life of Kinnow (Citrus reticulata Blanco). The J. Anim. Plant Sci. 28(2): 520-526.

Rayees Ahmad Shiekh, Maqsood Ahmad Malik, Shaeel Ahmed al-ThabaiTi and Muneer Ahmad Shiekh, 2013, Chitosan as a Novel Edible Coating for Fresh Fruits. Food Sci. Technol. Res., 19 (2), 139-155

Riaz, S. S., M. S. A. Tauseef, M. A. Imran, Rabia Shabir; et al., 2018.; Extraction of Polysaccharides from Opuntia Cactus for Its Potential Application in Edible Coating to Improve the Shelf Life Of Citrus (Kinnow Mandarin) Fruit. J Microbiol Biotech Food Sci, 8 (1) 745-750.

Ritesh Kumar, A. Ghatak, R. Balodi and P. B. Arun. 2018. Decay mechanism of postharvest pathogens and their management using non-chemical and biological approaches, J. of Postharvest Tech. 6 (1): 001-011.

Sabina Galus, Emine Aytunga Arik Kibar, Małgorzata Gniewosz and Karolina Kra sniewska, Novel Materials in the Preparation of Edible Films and CoatingsA Review, Coatings 2020, 10, 674; doi:10.3390/coatings 10070674

Saha, A., Tyagi, S., Gupta, R. K., \& Tyagi, Y. K. (2017). Natural gums of plant origin as edible coatings for food industry applications. Critical Reviews in Biotechnology, 37(8), 959-973. doi:10.1080/07388551.2017.1286449

Saleem, M. S., Ejaz, S., Anjum, M. A., Nawaz, A., Naz, S., Hussain, S., Ali, S., Canan, İ. (2020). Postharvest application of gum arabic edible coating delays ripening and maintains quality of persimmon fruits during storage. JFPP. doi:10.1111/jfpp.14583

Salgado, P. R., C. M. Ortiz, Y. S. Musso, L. Di, Giorgio and Mauri, A. N. 2015. Edible films and coatings containing bioactives. JCOFS. 5: 86-92. doi: 10.1016/j.cofs.2015.09.004

Sapper, M. and A. Chiralt. 2018. Starch-Based Coatings for Preservation of Fruits and Vegetables, MDPI, Coatings. 8: 152. doi:10.3390/coatings8050152

Shahid, M.N. and Abbasi, N.A., 2011. Effect of bee wax coatings on physiological changes in fruits of sweet orange cv. Blood red. Sarhad Journal of Agriculture. 27(3): 385-394.

Sharmin, M., M. Islam and M. Alim. 2016. Shelflife enhancement of papaya with aloe vera gel coating at ambient temperature. J. Ban Agril. Univ. 13(1): 131.

Shendurse,A.M., Gopikrishna, G., Patel,A.C.,

Shweta Chauhan, K. C Gupta and M. Agrawal. 2014. Efficacy of natural extracts on the storage quality of Apple. IJCMAS. 3 (3): $10-11$

Shweta, C., K. C. Gupta and M. Agrawal. 2014. Efficacy of Chitosan and Calcium chloride on Post harvest storage period of Mango with the application of hurdle technology. IJCMAS. 3(5): 731-740

SimaPanahirad, Rahim Naghshiband-Hassani, Sara Bergin, Ramesh Katam and Nasser Mahna, Improvement of Postharvest Quality of Plum (Prunus domestica L.) Using Polysaccharide-Based Edible Coatings, Plants 2020, 9, 1148; doi:10.3390/plants9091148

Sneha, N., M., A. Saxenaa and C. Kaur. 2018. Effect of chitosan and alginate-based coatings enriched with pomegranate peel extract to extend the postharvest quality of guava (Psidium guajava L.). Food chem. 240: $245-252$

Tesfay, S. Z., Magwaza, L. S., Mbili, N., \&Mditshwa, A. (2017). Carboxyl methylcellulose (CMC) containing moringa plant extracts as new postharvest organic edible coating for Avocado (Persea americana Mill.) fruit. Scientia Horticulturae, 226, 201-207. doi: 10.1016/j.scienta.2017.08.047

Tripathi, P., and N. K. Dubey. 2004. Exploitation of natural products as an alternative strategy to control postharvest fungal rotting of fruit and vegetables. J. Postharvest Bio and Tech. 32(3): 235-245.

Valencia, G. A. and P. J. do Amaral, Sobral. 2018. Recent Trends on Nano-biocomposite Polymers for Food Packaging. Polymers for Food Appli. 101-130.

Xiao-yu Li, D. Xiao-long, L. Ying, T. Lin-jing, 
W. Qian and L. Jian-long. 2019. Rhubarb extract incorporated into an alginate-based edible coating for peach preservation. Scientia Hort. 257: 108685

Yang Xing, Qinglian. Xu, Xingchen Li Cunkun Chen, Li Ma, Shaohua Li, Zhenming Che, and Hongbin Lin. 2016. Chitosan-Based Coating with Antimicrobial Agents: Preparation, Property, Mechanism, and Application Effectiveness on Fruits and Vegetables. Inter. J. of Polymer Sci. 1-24.

Yossef, M. A. 2014. Comparison of different edible coatings materials for improvement of quality and shelf life of perishable fruits. Middle East j. Appl. Sci. 4 (2):416-424.

Zhang, L., Chen, F., Lai, S., Wang, H., and Yang, H. (2018). Impact of soybean protein isolate-chitosan edible coating on the softening of apricot fruit during storage. LWT, 96, 604-611. Doi: 10.1016/j.lwt.2018.06.011

Zhi. H., Y. Dong, and Y. Wang. 2018. Effects of controlled atmosphere, edible coating, and 1-methylcyclopropene on improving storage quality of "Bartlett" pears after long-term storage. J. of Horti. Sci and Biotech, DOI: 10.1080/14620316.2018.1450098

Zillo, R. R., P. P. M. da Silva, J. de, Oliveira, E. M. da, Glória and M. H. F. Spoto. 2018. Carboxymethylcellulose coating associated with essential oil can increase papaya shelf life. Scientia Hort. 239: 70-77.

\section{How to cite this article:}

Susmitha Reddy, K. and Jatinder Singh. 2020. Edible Coatings in Fruits - A Review. Int.J.Curr.Microbiol.App.Sci. 9(11): 2953-2969. doi: https://doi.org/10.20546/ijcmas.2020.911.359 